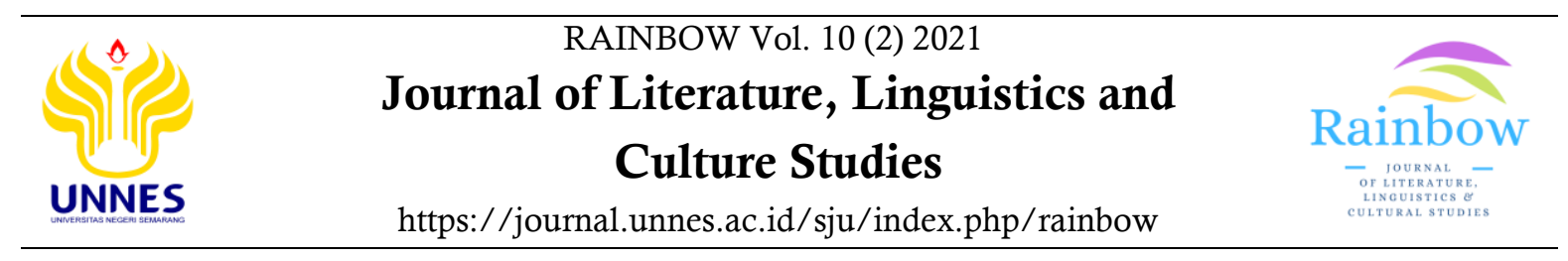

\title{
Who is afraid of the gods? Rethinking escapism in Nigerian dramatic literature
}

\author{
Olutoba Gboyega Oluwasuji ${ }^{凶}$
}

Faculty of Humanities, Social Science \& Law, Walter Sisulu University, Mthatha, South Africa

\begin{tabular}{|c|c|}
\hline Article Info & Ibstract \\
\hline $\begin{array}{l}\text { Article History: } \\
\text { Received } \\
\text { 09 June } 2021 \\
\text { Approved } \\
\text { 26 October } 2021 \\
\text { Published } \\
\text { 30 October } 2021 \\
\text { Keywords: } \\
\text { African gods, } \\
\text { connective theory, } \\
\text { escapism, machination, } \\
\text { misinterpretation }\end{array}$ & $\begin{array}{l}\text { Escapism can mean different things to diverse sets of people in various fields of study. To } \\
\text { some people, it can mean escape to reality, while some can denote it as an escape to } \\
\text { entertainment or distraction from boredom. Escapism in this paper takes a different turn } \\
\text { and adopts the term to identify how different decisions can be influenced in any socio- } \\
\text { cultural setting. Using Southwestern Nigeria as a case study, this paper questions the } \\
\text { possible interpretations of escapism and the extent to which leaders identify with them. } \\
\text { This paper uses Ahmed Yerima's Sacred Mutters (2013) and Iyase (2016) to explore the issue } \\
\text { of misinterpretation and human machination to escape punishment from the gods. The } \\
\text { plays highlight leaders' plight before their ascension into power, and the issue of human } \\
\text { carelessness, and how he or she is misguided by his or her own intellectual and spiritual } \\
\text { interests. The paper argues that modernization and Westernisation had crippled most of } \\
\text { the significant and core aspects of African norms, values, and traditions. This degradation } \\
\text { has affected the criminal justice system of the people. Against this background, the paper } \\
\text { adopts Olawole Famule's connective cultural theory (2015) to explore escapism, } \\
\text { misinterpretation, and machination in the Nigerian discourse. The paper concludes that } \\
\text { escapism is the main cause of corruption in the socio-political landscape of Nigeria and } \\
\text { calls for a return to traditional African system. }\end{array}$ \\
\hline
\end{tabular}

C) Copyright 2021

How to cite (in APA Style):
Oluwasuji, O. G. (2021). Who is afraid of the Gods? Rethinking escapism in Nigerian dramatic literature. Rainbow : Journal of
Literature, Linguistics and Culture Studies, 10(2), 81-95. https://doi.org/10.15294/rainbow.v10i2.47239

\section{INTRODUCTION}

Nigeria is a multicultural nation with a diverse belief system, and each holds significance in the development of its people. Due to exposure to western culture, people have forgotten their heritage and have embraced the tenets of the Western religion. The knowledge about African gods is being swept under the carpet. Instead, African people are 'brainwashed' to know that there is a place for grace if they embrace the Western religion of Christianity, for example. As a result, crime and fraudulent acts are rampant both in government and in local authorities.
Noteworthy is Mbiti's view on the African religion. John Mbiti emphasizes that:

African religion is traditionally integrated into the whole of people's lives, it would feature prominently in for example family and communal rituals to mark the rites of passagebirth, initiation, marriage, pregnancy, parenthood, death, burials, contact with the invisible spirit world. Some individuals would be trained and designated to perform special duties for their communities, such as healers (doctors), diviners, priests, prophets, kings/queens, ritual elders (both men and women), forecasters or rain and locust invasions, or epidemics, etc' (Mbiti, 2015, p. x).

\footnotetext{
Corresponding author:

E-mail: suiitoba@vahoo.com
} 
No one is devoid of the society in any African community. Hence, no African child is born in isolation. He or she is born into a community that consists of visible and invisible members, the living and the ancestors. The community will always be more important than the individual. Membership of a community is not perceived as a loss of individual freedom as modernist will make the excolonised to believe but as a necessary part of living a complete life. Every individual is integrated into a network of relationships that comprise, firstly, the larger family circle, then the tribe or clan, then the ancestors, and then nature and Supreme being (often referred to as Olodumare in the Yoruba language). This signifies that everyone born in Africa is conversant with religious codes and conducts. However, Christianity, Islam, urbanization, modern technology, atheism, internet blogs, political transitions, intertribal or ethnic wars, etcetera, all influence the belief system in Africa. This agrees with Ogunleye Richard (2015) as he describes Western education, civilization, modernity, science, and technology as factors that contribute to African people's understanding of indigenous worship as barbaric, uncivilized, and outdated (p. 65).

Speaking on the influence of modernity and the emergence of Western civilization and urbanisation, Ogunleye opines that, 'the Yoruba people, for example, are dangling between the traditional and the so-called sophisticated western mores and value system and had not even got to the other end before the traditional one collapsed, so we are in a total vacuum' (p. 65). These factors have encouraged escapism as a form of avoiding the wrath of the gods that maintain codes and conduct in the community. For example, in Yorubaland, all the gods work together to maintain sanctity in the community. In Yoruba mythology, Olodumare (the Yoruba version of Supreme God) is the 'Almighty' with sixteen ministers serving as intermediaries between him and mortals. He is too great and remote to access. Olodumare pervades everything and represents the ultimate source of humankind's well-being. He is not involved in people's everyday lives, and no prayers, worship, or sacrifice are offered to the supreme being. The ministers are being worshipped and held in high regard with weekly, monthly, or yearly festivals offered to them. The ministers include Orunmila, the god of wisdom; Obatala, the god of creativity; Ogun, the god of iron; Osun and Oya, the river goddesses; and Sango, the god of lightning (Jegede, 2006, p. 256; Ribeiro 1997, p. 243). These gods have different portfolios in the mythology, and they are believed to be the creator of the earth (see Bolaji Idowu, Olodumare God in Yoruba Belief (1962); and Omosade Awolalu, Yoruba Beliefs and Sacrificial Rites (1979). As such, on getting to the planet earth, they form a political system where they oversee a particular community aspect. For example, Ogun works with Sango to maintain peace and order in the community. When an individual is perceived to commits a crime in Yorubaland, he or she will swear with an Ogun implement to prove his or her innocence. If found guilty, $\mathrm{He}$ or she will die as a result of an ironrelated implement if guilty. The judgment is instant as compared to the western religion of grace and mercy. Fear of the instantaneous judgment of the gods helps to ward off corruption or evil from the community ${ }^{1}$.

Furthermore, the high level of crime and corruption in African societies calls for a return to using traditional methods to maintain peace and order and instill the knowledge about African gods that has been lost to modernity. Although different communities still have a way of punishing offenders, people still hide under the second chance provided by Western religions to change their ways. For instance, there are over 38 verses in the bible about god's mercy and a second chance (Exodus 34:6-7; Deuteronomy 7:9; Psalm 145:8-9).

\footnotetext{
${ }^{1}$ Other form of swearing by the gods is exemplified in Michael Monye's (2004) description of how oath making is done by Ogun believers: water is used to wash the interior and exterior parts of a gun and poured into a bowl, thereafter the suspects are called to stand and pronounce that if he/she is responsible for the charge levelled against him/her within seven days, Ogun should strike.
}

Consequently, the bowl containing the water is passed round for them to drink from. Incidentally or perhaps accidentally before the expiration of the agreed date fatal misfortunes befalls the culprit if not outright death. Taboos abound in Yorubaland. 
As such, people turn to persistent offenders as a form of escapism from instant judgment and punishment from African gods. Okunola and Ojo (2012) opine that 'punishment is an innovation with which society wards off the siege of the criminal, and the perceived seriousness of the offence being dependent upon the goals of those in charge, who are the people who represent their society. The most serious of crimes are sometimes punished with death, although what is considered to be a serious offence is subject to the views of the society in which it occurs' (p. 1057). For example, a murderer in South Africa can still serve a jail term for murder, while in Nigeria, such an offender is liable to death by hanging or electrocution in Nigeria (Sections 33(1) and 34(1)(a) of the 1999 Constitution). Punishing offenders is not to seek vengeance for the victim of the crime but to make life and property more secure by reducing the likelihood of committing a crime or a second offense. There is wisdom embedded in punishing offenders as people learn from mistakes. Punishment brings knowledge, and it is also an act of healing wickedness (Dressler, 2015, p. 859).

Okunola and Ojo (2012) aver that there are two forms of punishment, formal and informal, that can be applied to correct crime in society ( $p$. 1058). On the one hand, following the modernized institutionalized agencies such as the law court and other criminal justice systems to assign punishment, the first form is formal. Such formal punishment can be categorized into capital punishment, corporal punishment, imprisonment, and other miscellaneous punishments backed by the constitution of the society. On the other hand, following the cultural specifics and prescriptions in exercising punishment, the second form is informal. Offenders may be punished by ostracism, flogging, boycott, sacrifice, payments of fines, and exile. Okunola and Ojo further highlight two primary forms of informal administration of punishment. First, the offender's conscience as the wrongdoer considers what will happen if such a crime is committed and will not do such again. Second, the representatives or acolytes of the gods in the community will evoke ancestral spirits or gods to intervene regarding the crime committed.
Thus, this paper adopts the second form of informal punishment administration to address the country's problems in terms of corruption and build a shared national vision of a corruption-free nation. The research will focus on how Ogun, Sango, Oya, and Esu, serve as supernatural agents of punishment among the Yoruba of South Western Nigeria. As mentioned earlier, the traditional African society is sacred, and the secular is inseparable from it. There is no separation of life from religious aspects. What religion forbids or condemns, society also forbids and condemns. Nwangama (2014) avers that 'African traditional religion is anchored on the concept of justice and human dignity because religion serves a useful role in enforcing moral codes in the society' (p. 704). When one commits a crime against a fellow human in the community, such offense is against the gods. Punishments are meted out to offenders to appease the gods, who might have expressed their anger through plagues, or other desolation, to lessen their anger.

The questions that arise are, what if the offender is a Christian or Muslim? Will the gods punish him if he or she is guilty after swearing using the informal form? What if the offender is a worshipper of Obatala, and he or she is requested to swear with an Ogun symbol? Will the gods still punish the individual if found guilty? Bearing in mind that every African child is born into a homestead, and every home has its tradition. Swearing and curbing crimes are still very strong in traditional Africa settings. Although Westernization and modernity have crippled traditional values, swearing by our gods can be the most effective way to curb crime because, through them, there is no way for one to escape. It is surmised that despite the introduction of modern policing, court, and penal system, the African society is still wallowing in high statistics of criminal cases that were not part of the pre-colonial African societies. African people have abandoned their philosophy and have embraced the western version, which fails to proffer a solution to the growing crime rate and corruption. The recent outbreaks of violence, kidnapping, thuggery, and bombing are signs of alien cultures, indicating that 
Africans have lost their authentic identities (UtohEzeajugh \& Ogbonna, 2013, p. 14; Oluwasuji, 2019, p. 78). ${ }^{2}$ Consequently, African people no longer respect or fear the criminal justice of Precolonial Africa, hence, recidivation among the offenders. The angst that the African gods will punish anyone that breaks societal code severely no longer exists or is no longer in operation.

To avoid immediate judgment or wrath from the gods, people hide under the Western religions as a means of escapism. For instance, in an interview with Soyinka, Jeyifo proclaims Ogun to be a bloodthirsty god and loves gore and one who destroys at will (Jeyifo, 2004, p. xviii). Due to the fear of what Ogun might do to anyone who promises and fails to fulfill, the Yoruba people avoid swearing with an iron implement or drink blood as a symbol of an oath. This belief extends to other gods in Yorubaland. For example, no one wants to swear in the names of Sango or Oya and do otherwise. Oyeshile Alabi (2010) also affirms swearing by Ogun, the god of iron, can be dangerous to a person making unrealistic promises. According to Oyeshile (2010), 'government officials swear under false oath and forge certificates and other documents. Many Nigerians swear falsely with the Bible and Quran and yet go ahead to commit untold atrocities. The Christian and Moslem God must be extremely kind to Nigerians. You dare not swear falsely with Sango -god of thunder, or Ogun -god of iron' ( $p$. 57). It is noteworthy here that Nigerian politicians opt to swear with the Bible or Quran during their inauguration or swear-in-ceremony. For instance, Salisu further refers to a former Speaker of the Nigerian House of Representatives, Alhaji Salisu Buhari, who forged his university certificate from Toronto University and embezzled governmental fund. Salisu was convicted and sentenced to two years in prison with a fine. As usual, he paid the fine and pardoned by President Olusegun Obasanjo's regime. If Salisu, for example, had been subjected to swear by Ogun or Sango during his swear-in-ceremony, he would not have dared forged his certificate or embezzle any governmental fund. A cheat and lair of such would have been eliminated from the community to not corrupt the coming generation. The distortion of what is 'African' at the expense of what Westernization term to be a 'religion of grace and mercy' is referred to as escapism in this paper.

\section{THEORETICAL CONSIDERATION}

Western terminologies and theoretical frameworks have since summed up many types of research emanating from the ex-colonized world, especially Africa. Famule (2005, p. 35) opines that 'until the late sixties, African art history research had been predominantly in the hands of the Western scholars who often approached it with the Western theoretical frameworks. Ranging from poststructuralism, postcolonial, new historicism, readers response, Marxism, new criticism, narratology to feminism, Western ideologies have populated the ideas of the proponents. It is noteworthy to mention that there have been several significant African versions of these theories. For example, African scholars have produced some of the most influential feminist ideas in the world. Examples of such are Chikwenye Okonjo Ogunyemi's womanism (1985), Molara OgundipeLeslie's stiwanism (1994), Mary E. Modupe Kolawole's African womanism, and Obioma Nnaemeka's nego-feminism (2003). Although the core of this paper is not feminism, it agrees with the notion that African researches should be analyzed within its cultural context. Western culture is unique in its entirety and different from African culture. This paper supports the idea that Africangenerated ideas should be applied to African literary analysis. Owing to cultural differences between the Western and African arts, some aspects of African performances might seem

\footnotetext{
${ }^{2}$ An effort has been made by the Yoruba people since the Western judicial system is not working for them. Recently Fulani herdsmen from the north have been killing, kidnapping and raping people in the farmland. The South Western governors agreed to create a traditional policing system called 'Amotekun' (Oyetunji, 2020). Amotekun recruits local hunters who can be regarded as Ogun
}

principles in the community. They are formed from the existing Odua people's congress. Hunters and warriors in Yorubaland are characterised as Ogun's symbols among the people (Okunola and Ojo, 2012, p. 1063) 
barbaric or outdated to the former. Against this background, this paper will adopt Famule's connective cultural theory to explore the issues of escapism, misinterpretation, and machination in Nigerian discourse.

According to Famule (2005, p. 36), 'connective theory' is a locally sourced cultural theory that relies on the fact that African art, the example of Egúngún (masquerade), is essentially an assemblage or composite of a diverse component. 'Locally sourced' means the theory emanates from Africa, as Famule is a Nigerian. Connective theory discusses the issue of culture and how elements from African cosmology and mythology interconnect. Applying an African-originated conceptual framework, connective theory, depicts this paper as a reflection of common occurrence in Africa, both in the social and political sphere of the people's life. Famule's connective theory shows how elements of African performances interconnect or co-exist. The approach can assist in determining how events and characterization in the two plays help unveil significant themes on machination, escapism, and misinterpretation. Famule posits that 'connective theory examines the materials that made up a composition individually and then establishes their connections points. This theory could answer 'why specific materials and not the others were used in making a given African artwork' (Famule, 2005, p. 36). Famule's position is relevant to understanding how events in the plays relate to each other. Famule's connective theory assists in understanding the politics at play in both texts and how some characters misinterpret African values.

Connective theory is relevant in discussing both plays as it could assist in understanding why some events develop. A playwright could decide to bring an event that most audiences would expect to find at the end of the play to the beginning, which might sometimes be confusing to an audience. Connective approach could be employed to analyse elements such as space, music and songs, dance, role-playing, and costumes in the selected plays to deal with the confusion. According to Famule's proposition, the connective approach assists in determining why a particular action takes place instead of another. It could also be used to unravel why a particular character in the selected plays adopts escapism after intentionally or unintentionally misinterpreted a code of conduct in their community.

\section{METHODS}

The paper adopts a textual analysis of both Ahmed Yerima's Sacred Mutters (2013) and Iyase (2016) as the primary sources of data to identify how escapism has been the major cause of corruption in the socio-political landscape of Nigeria. The two texts represent a typical story of Nigerian leaders who in one way or the other, have hidden under their religious affiliation to avoid justice. The study uses descriptive qualitative research method to analyze existing data. A descriptive analysis is narrative in nature; it observes, describes, and documents aspects of a situation as they occur (Bamgboye, 2020, p. 34). A descriptive analysis method is a systematic study or observation of people's experience. The method is about understanding people's views of social issues by observing their behavior in natural settings. (Ospina, 2004, para. 1279).

Diora and Rosa posit that 'descriptive qualitative research refers to an investigation which utilizes existing data or experimental research' $(2020$, p. 88). The characters and events in Sacred Mutters (2013) and Iyase (2016), were analyzed to conclude that a return to the African traditional judicial system could benefit the communities and ward off leadership and followers' corrupt practices. Using Famule's connective theory (2015) also assists in knowing the correlations between events in both plays.

The secondary sources of data collection are government policies, newspaper articles, academic articles. Current events in some Yoruba states, such as Ekiti and Ondo, were used as examples to emphasize how the African traditional judicial system has helped reduce criminal activities. For example, the creation of Amotekun Judicial System assisted in curbing the surge of Fulani Herdsmen in the Southwestern part of Nigeria (Oyetunji, 2020). Hence, Yerima's texts 
experimented with history to represent what is currently affecting the Nigerian judicial system.

\section{PRESENTATION OF THE TEXTS}

Rantimi Adeoye (2013, p. 68) classifies Ahmed Yerima among the third generation playwrights who have received tutelage from the first generation playwrights such as Wole Soyinka, Ola Rotimi, and J.P Clark. According to Adeoye, Yerima also understudied second generational playwrights such as Femi Osofisan, Olu Obafemi, Bode Sowande, and others before flourishing himself as a renowned playwright in the 1990s. Due to this experience, Yerima became the Deputy Artistic Director of the National Troupe of Nigeria and, eventually, Artistic director of the National Troupe of Nigeria from 2000 to 2009. Gbemisola Adeoti (2005) appraises Yerima as:

... one of the most notable dramatists to have emerged on the Nigerian literary drama stage in the last decade of the twentieth century. Apart from being a playwright, he is an artistic director, a theatre manager, a teacher and a researcher [...] Yerima's dramaturgy combines the practical orientation of a theatre practitioner with the aesthetic consciousness of a critic. $\mathrm{He}$ draws broadly from generic elements of tragedy, comedy, tragic-comedy and satire; freely experimenting, in a sometimes eclectic manner, with theatrical forms known in theatre history' (p. 3).

Yerima has published over 40 plays; Three Plays in Transition (1980), The Silent Gods (1996), The Bishop and The Soul with Thank You Lord (1996), The Trials Of Ovoramwen Nogbaisi (1998), Kaffir Last Game (2001), Attahiru (1999), The Lottery Ticket (2002), Dry Leaves on Ukan Trees (2001), Yemoja (2002), Otaelo (2003), Limam and Ade Ire (2004), The Angels and Other Plays (2004), Hard Ground (2006), Ameh Oboni The Great (2006), Idemili (2006), Aetu (2007), The Wives (2007), Tuti (2008), Akuabata (2008), Mojagbe (2008), The Little Drops (2009) and Orisa Ibeji (2014). The numerous dramatic themes in these plays include leadership crisis, military misadventure, national unity, political and ethnic rivalry, state oppression, political corruption, poverty, inadequate health care, environmental problems, and other socioeconomic issues encountered by Nigerian society.

For instance, in Sacred Mutters (SM), Oba Adekanbi became the king of the Adeowo community due to his supposed mother, Olori Abike's, crooked means of influencing the decision of the town's kingmakers through Esu (SM, p. 41). Olori Abike consulted Esu's priest Saura to confuse the kingmakers to favor Oba Adekanbi's enthronement. The play commences with Saura, the town's Esu priest, complaining about people who visit his shrine, making promises that they fail to fulfill (SM, p. 39-40). Yerima presents Saura as a narrator of Oba Adekanbi's rejection and death and the aftermath of his demise. Saura recounts how the people paraded him to the palace, stoning and singing abusive songs of his responsibility in Oba Adekanbi's misrule. Adekanbi consulted Saura to evoke Esu to help him become the king of Adeowo. He makes countless promises which he did not fulfill. During his visit, Saura emphasizes that Esu does not change people's destiny but rather tampers with it and requests Adekanbi to make love to a madwoman, as the only sacrifice to Esu (SM, p. 43). Adekanbi's bid to become the king became successful, and Saura warns him never to set eyes on the madwoman till he dies. In the event Adekanbi sees the madwoman, Saura forwarns that the community will experience confusion. Unfortunately, when Adekanbi was having sex with the madwoman, the latter seized Adekanbi's bead and complained that the intending king took her without permission. As Saura predicted, confusion arose on Adekanbi's coronation when the madwoman returns with the king's royal bead. The madwoman turns out to be Adekanbi's biological mother, who, since she went berserk, resides beside a river that Oya, the Yoruba river goddess, inhabits ( $S M$, p. 47). The council of chiefs queries the madwoman's presence and her possession of the royal bead during the new king's coronation ( $S M$, p. 59).

Iyase (IY), on the other hand, explores the issue of leadership, corruption, and misinterpretation of cultural codes. The play's 
setting is Benin, Edo State, Nigeria. ${ }^{3}$ It reinforces the overlapping of cultural code from Yorubaland to Benin, Edo State. In the text, Iyase, the prime minister to the king, adopts Ogun, Yoruba god of iron, as his god. He takes inspiration from the tenets of Ogun (IY, p. 22). The play reaches climax from the beginning when Iyase found out that his third and favorite wife is having an affair with Edaiken, the heir to the Benin throne. Iyase furiously slaughtered his wife, Ivie, in the Ogun shrine in his house. He claims Ivie's head is a sacrifice to atone Ogun due to his wife's infidelity. During the sacrifice to Ogun, Iyase's blind mother, Omosefe, cautioned him from taking further actions. While they both planned to hide Ivie's headless body, Omosefe warned Iyase that the gods forbid an attack on Ediaken because the gods had ordained him to succeed the king and that Ivie's death is a forbidden meal for the gods. Iyase stormed out of the shrine to seek revenge on Ediaken. He decided to visit his childhood friend, Osodin, the Benin army commander, before confronting Edaiken (IY, p. 20). Iyase met Baba, a Yoruba diviner from Ile-Ife, in Osodin's house. Baba warned him not to attack the crowned Prince to avoid invoking the wrath of the gods. Recalcitrant, Iyase prepared for war against Edaiken. Upon realization that he could not win the fight against the gods and Benin Kingdom, Iyase committed suicide by asking his blind mother to wield the sword during the preparation for the war against Edaiken.

\section{DEDUCTIONS AND ANALYSES}

Although Oxford Dictionary defines escapism as the tendency to seek distraction and relief from unpleasant realities, especially by seeking entertainment or engaging in fantasy, Young Warren's definition will serve as a point of departure in understanding what escapism is and its relation to the socio-cultural discourse in Nigeria. Young defines escapism as a value-leaded term - this means that there has been attached to the word an ethical connotation, which, it seems, has created a social stigma association. The social stigma appears when the word is used as a noun, or transformed into an adjective as escapist, or when used as the verb in a context of escape from a situation by creating one which appears to the creator, before he has experienced it, to be better than that in which he finds himself. (Young 1976, p. 377)

Looking at the grammatical function of the word 'escapism', it is pertinent to note that the main characters in both plays, Adekanbi and Iyase, both identify a means of escaping the wrath of the gods after they realized their mistakes. Both characters forms of escapism led to death. Hence, Young's classification of escapism lends a hand in understanding the characters' actions. According to Young (1976, p. 377), there seem to be two senses of escapism: the traditional sense and the dynamic sense. One's discretion guides the traditional sense of escapism. It is innate and not subjected to communal or societal demand. It is often an attempt to find personal satisfaction and a means of escape from the situation one finds himself or herself. Factors that could make an individual seek traditional escape are character weakness, self-improvement, and intellectual triumph. Looking at Young's classification, character weakness could result from an inferiority complex, which could impact an individual's decision to consider death as a means of escape. When such an individual finds out that he or she is being oppressed or bullied out of a situation, he or she consider self-improvement or what Young terms as 'moral triumph of advancing' (Young, 1976, p. 377). However, some individuals use the opportunity to seek solace in other religions or beliefs, thereby abandoning their faith as a process of 'discovery' (Young, 1976, p. 377).

The second form of escapism which is also relevant to the discussion is dynamic escapism. Young sees dynamic escapism as 'consisting of a
${ }^{3}$ While commenting on the Yoruba influence and migration of gods from Yorubaland to Benin kingdom, Idumwonyi and Ikhidero (2013) avers that 'there is a pantheon of divinities in the Benin ontology and each divinity occupies a location where they maintain their status' (p. 130). These divinities either manifest the wrath or blessings of the Supreme Being. They include oronmila[Sic; might be due to Benin orthography], sango (god of thunder), ogun (god of iron), eziza (god of whirlwind), ayelala, olokun (the sea goddess of wealth and prosperity), and so on. 
concentration on daily affairs, a concentration with a sense of altruistic humanism, but altruism consisting of social consciousness, an effort at the betterment of the entire human situation. It is a course of action, not of hope, action for the betterment of man in his world, and maintaining the balance between man and his world' (p. 378). This form of escapism comes when one realizes his or her action and determines to find a solution to the havoc he or she has caused. At this stage, the individual no longer fears death or the reward for his or her actions. Wamerlink, Harteveld, and Mayer (2009) opine that 'escapism is quite therapeutic' (p. 1). Hence, both traditional and dynamic forms of escapism will be used to explore how misinterpretation and machination influence people's decisions in both Sacred Mutters and Iyase.

Using connective theory, both plays start with offering sacrifices to gods. While Sacred Mutters commences with Saura offering libation to Esu, Iyase begins with ritual rites to Ogun in the shrine. Both plays emphasize how different gods in Yorubaland comes to ascertain peace in their respective communities. ${ }^{4}$ How does escapism lead to incurring punishment from the gods? Misinterpretation of cultural codes by Adekanbi and Iyase in both plays becomes grievous mistakes that led to the collapse of the perpetrator's community. Noteworthy is how both plays explore the influences of African gods such as Ogun, Sango, Esu, and Oya in punishing offenders and warding off evil from the community.

The first scene in Sacred Mutters highlights the misinterpretation people have of Esu, the Yoruba trickster god. The play treats the subject of citizens' fate in a country dominated by corrupt leaders. Sacred Mutters explores the plight of leaders before ascension to power. A narrative of a Yoruba prince aspiring to inherit the throne of his father despite him being the twentieth son of the late king ( $S M$, p. 41) develops throughout the play. Adekanbi already has an affiliation with Ogun, the Yoruba god of iron, but approaches Esu to escape the reality that Ogun is not interested in manipulation. It becomes vivid later in the play when Adekanbi mentions that 'May Ogun forgive me. Haa, Baba Saura warned me' (SM, p. 55). He realized that he had made a mistake by fraternizing with Esu. Looking at Adekanbi's intention from a connective theory standpoint, he is the architect of his downfall. Adekanbi mentions how he intends to manipulate the existing code and conduct of his community in the following conversation:

Saura: I should have known. A spitting image of the late king. The night draws near. Here. (Gives him a pebble.) Your mother says you want to be king after your late father?

Adekanbi: Yes Baba.

Saura: Pour your mind to the pebble. Tell it what you want from Esu.

ADEKANBI: I am the twentieth son of the late king by his wives. Olori Abike has only one son, me... we are twenty-five sons in all. And we all want to be king after our late father.

SUARA: Listen young man, Esu does not change the destinies of people as set by Olodumare. He only tampers just slightly with it. Helps man to achieve his destiny a trifle quicker. So, to the point, young Prince, my master is also a restless god. One million things to do, and usually, no time. To the point, I beg you. (SM, p. 42)

Young's view on character weakness and the quest for self-improvement is evident in the above extract. Although overambitious, Adekanbi feels relegated and wanted to be king despite being the twentieth son of his father. In Yorubaland, accession to the throne is often through primogeniture, as the right of succession belongs to the firstborn male child. According to Ernest Ugiagbe et al., 'the Benin/Edo, Igbo, Efik, Yoruba, and Hausa ethnic groups in Nigeria are examples of peoples practising patrilineage, albeit with varying degrees of differentiation' (2007, p. 91). The choice of a firstborn son being the successor relates to him having the responsibilities of being a father, husband, brother, and uncle. He might

\footnotetext{
${ }^{4}$ Language usage can sometimes cause confusion. Esu in this contest should not be confused with the Christian Satan. Esu is not evil as a modernist might portray him. According to Balogun, 'another divinity that is always being associated with evil is known

as "Esu". While it is true that "Esu" is capable of doing evil, it will be totally incorrect to perceive "Esu" as an all-evil being like 'Satan' of Judeo-Christian thought' (Balogun, 2009, p. 7). 
have, through several times, learned how his father performs some rites and roles as a king. However, the rule of ascension to the throne can vary with respect to religion or choice by the oracle. The degree of difference develops the tension in the play; Oba Adekanbi tends to break the order by seeking Saura's help to manipulate the decision of the oracle and kingmakers. The quest of Oba Adekanbi brings calamity to the community in different shades as Esu got jealous of Adekanbi's association with Ogun. Ifadare, the village diviner, later mentions that 'Esu is angry with him [Adekanbi] because he thinned out his covenant with Esu by bowing to other gods and belittled Esu's eminence ( $S M$, p. 55). Using connective theory assists in answering the question of 'why should a single person's act put a whole community in danger?'

Similar to Iyase's ordeals in Iyase, Adekanbi's act results in social disorder in Adeowo village. In Iyase, Edaiken had an affair with Iyase's wife on the latter's marital bed, and when caught in the action, the former seems not to be remorseful of his actions. Edaiken's actions make Iyase feel relegated and reduced to the status of nobody. Despite his despicable act, Edaiken summoned Iyase as the prime minister to prepare for his coronation. Unfortunately for Iyase, according to the Benin custom in the text, he 'will be the one to announce the king's passage and must make sure that Edaiken is made king, and the gods have accented to that' (IY, p. 32). Iyase feels violated and confronted Edaiken in the following conversation when he was asked about his stand in the coronation matters:

IYASE: Where I stand...is shady. Blurred by my fading sight. All I see is my Edaiken naked with my wife on my matrimonial bed. And even after I caught you, you took your time. You casually dressed up in my room, with my naked wife looking on.

EDAIKEN: I saw you stupefied. Frozen like a carved stone. I knew that moment of shock was all I had. And when I stood before you, you bowed and stepped aside. So I walked past.

IYASE: Unworried. Unperturbed.
Yes. Like the royal man that you are. You even acknowledged my bow. Do you want to know where you really hurt me ...when you plunged a knife into my essence...my Prince?

EDAIKEN does not speak.

IYASE: When even as I stood by the door, you ignored my person.... you spat on burning anger and tied the beads on her neck. With your left hand, you ran it down her face to her naked left breast... my breast. (IY, p. 44)

Iyase's confidence to confront the heir apparent, who had been consented to by the gods and no one can kill, depicts that he is not scared of the consequences. Since revenge is not possible on Edaiken because of his immunity from the gods, Iyase seeks a traditional form of escapism. Young (1976) sees this type of escapism as an 'attempt of the individual to escape the drudgery of the situation he finds himself; an attempt to provide himself with a personal utopia' (p. 377). It is evident from the above that Iyase is deeply hurt and feels a kind of character weakness that can only result in death since the gods forbid an attack on Edaiken. Iyase seeks solace in his admiration for Ogun. He sacrificed his wife to atone Ogun thinking that the blood of his wife will make Ogun change his mind to fight his course, as evident in the below:

Iyase: Ogun! Ogun! One with the restless red eyes. The Volcano that erupts on those who tend it. Death encased in the rock of steel! Obiligbo. Iron! My blood boiled again today. See how it boils over. See the avalanche of anger and boiling turmoil of my heart. I rage Ogun. See. (Shows the shrine the knife that he holds.) Why? What have you done to me Onire? Why? It is only you I worship! Then why did you turn your back to me? Why? You who brought me to great heights until my rich coral beads shone next to the Omo n'Oba, then why did you throw on my head the shredded shameful cloth of a mad man? Why? Tonight, shamed, I am washed in the blood of my once beloved pearl. Ogun! I say what have I done to you? That you watched me fall...sunk. See! (Turns and carries IVIE's head by the hair.) Here I bring you your sacrifice. With my own hands I cut her, as deep as she cut me. The only woman I gave my heart. My wife. In my Chamber, I found them. Frozen in awe, I let him go. But she is...was....mine. I strangled the Dog first with my hands, and then I cut her 
as you like your meat. Take it. (IY, p. 7).

From a connective theory standpoint, Iyase's action is due to misinterpretation of what Ogun represents. Sacrificing Ivie to Ogun is a form of covenant or oath that he is willing to do anything Ogun will request him to do. Iyase's action portrays an adherent misinterpreting what Ogun represents in the community. Iyase relies heavily on the negative features of the god of iron and compares the redness of Ogun's eyes to fury. Although John Pemberton (1997, p. 165) associates Ogun's favorite color, red, with fury and aggression, the association is due to the influence of modernity. It is necessary to understand the redness of Ogun's eyes and the cause of it (see Oluwasuji, 2019, p. 52). Iyase's anger makes him embody the negative connotation of redness and fury. His rage also caused him to offer what later reveals as offering 'forbidden meat to Ogun' by his mother (IY, p. 8). Iyase's misinterpretation of Ogun symbols and his quest to escape character weakness is similar to Adekanbi's quest to escape inferiority complex.

After consulting Esu, Saura attested to the agreement of the gods to make Adekanbi the king. Hence, Esu's request for Adekanbi to make love to a madwoman is a form of price to solidify the demand. Adekanbi accepted after much persuasion from Abese, his servant. Using connective theory, Adekanbi's quest is proportional to Young's idea of 'self-improvement, ' which can lead to the discovery of all-inclusive metaphysical systems and may intoxicate the possessor to such a degree that he forgets the need of existence altogether' (Young 1976, p. 377). At this stage, a seeker of self-improvement from character weakness may be willing to comply with any theory or form of escape. Saura, in the below conversation, first worked on Adekanbi's emotions by making him feel less of himself:

Saura: Enhen, to each man his duty. Now Prince Adekanbi you want to be king, and when you are, will you be man enough to sit on the throne of your ancestors?

Adekanbi: I am a man. I shall be a good king.

Saura: Now you have invited Esu, there is no turning back. Open your mouth. (He throws into his mouth a piece of meat taken from the basket.) Chew! (ADEKANBI chews.) A covenant with my master Esu. This should see you through the deed with the madwoman. (SM 45)

Connective theory helps to unravel the essence of oath making and the causal effect from the above extract. The motif of meat-eating symbolizes that Adekanbi has compromised his belief in Ogun and has formed an allegiance with Esu. Although it is not vivid that Adekanbi is a worshipper or believer of Ogun during the above conversation, it becomes evident in his constant referral to Ogun in the play ( $S M$, p. $55,59,66,77,78$, 81) that he follows Ogun's tenets faithfully. His cultural romance with Esu shows his unfaithfulness. Due to his over-ambition, Adekanbi makes several promises to Esu, forgetting his association with Ogun. Adekanbi got carried away with the intention of Esu's assistance. He made several promises to Saura and assured him of the fulfillment when he gets to the throne:

ADEKANBI: Ase, Baba. (prostrates.) And if ... and when I become king... you shall enjoy countless and limitless privileges of the joy of knowing me... the king. I shall give Esu the prominence that he deserves. In fact, he shall be at par with Eledumare. ( $S M$, p. 42)

Adekanbi is trying to be too ambitious, and he unconsciously intends to equate Esu to the Olodumare. His promise to Esu is typical of how Nigerian politicians make countless promises in their manifestoes and forgets to fulfill them. The Nigerian political scene is characterized by unfulfilled promises by politicians to the electorates. ${ }^{5}$ While commenting on unfulfilled promises during Nigerian elections, Ike-Nwafor (2016) states that 'politicians' essence of unrealistic promises is to persuade the audience to vote for them at the polls. The fulfillment of these promises had always remained a mirage, and most Nigerians are resigned to them' (p. 15). During aspiration for positions in Nigeria, politicians exaggerate their plans to get the electorates to vote for them. For example, Ike-Nwafor lists some of the politicians' 
slogans during their campaign, most of which will 'never' be fulfilled during their time in office. ${ }^{6}$ From a connective theory perspective, it is vivid that Adekanbi's engagement with the worship of Ogun made him forget his promises to Esu.

In both plays, both Olori Atinuke and Omosefe, Adekanbi and Iyase's mothers respectively, play significant roles in compromising their sons' beliefs. They both introduced Esu to their children, which led to their downfall. Young's opinion on spirituality and discovery of one's true self becomes relevant here. Young (1976) opines that 'the development of self can only be realized when the individual's spiritual interests, those which he alone desires to follow, are followed by himself to the fullest extent' ( $p$. 378). Using connective theory, Adekanbi and Iyase's errors could have been abated if they had been allowed to follow their beliefs in Ogun 'to the fullest'. For instance, in Iyase, Omosefe brought Esu to the Iyase's household for protection. Esu, in his jealousy, confused Iyase to misinterpret Ogun's codes by slaughtering his wife as a sacrifice to Ogun. During Iyase's visit to Osodin, he met Baba, who reveals how Esu confused Iyase's household and caused a commotion in the family. From a connective standpoint, Esu made Ivie, who Itohan, Iyase's second wife, describes as 'pearl of the heart of Iyase' to cheat on him with the heir apparent who the god declares immune to any vengeance or attack. Esu's trickery in Iyase is evident in the below conversation between Baba and Iyase:

(BABA enters carrying a small mat and a white bag. he spreads the mat on the floor. he sits. Takes out his opele (tray) and his divination chain. He murmurs.)

BABA: Orunmila father of Ifa, I greet you. Ajagunmale the Ifa Priest in heaven, I salute you. I have washed my eyes, let me see. Talk to me. Um! Ogun what are you doing here? Is it not too far for you? Anger ke? What is this I see? Ogun on a horse, a shroud in his hands, his sword too, his face focused on anger, revenge? To whom Ogun? Great chief who brought Ogun into your house?

IYASE: Me Baba. I had never worshipped him until that day. The Oba sent me to a neighbouring village to represent him at the Isiokue Ugie Ogun where he displayed his magical powers. I was entranced...I took him home.

BABA: Ogun Onire. Yanka nnire olomi nile feje we, o laso nile fimokimo bora. Why are you angry? Ah! Who stands behind Ogun? Esu Ebita ke? His trickster smile on his face. Urging Ogun to blow hotter, who brought Esu Ebita to your house?

IYASE: My mother, she brought him to protect us.

BABA: Ebita ke? (Chuckles.) Then you do not know laroye. Ebora tiije latopa, obelekun sunkun keru o ba elekun laroye and ogun.

IYASE: The worshippers say I bear the Ogun spirit of Ogunbo, they say I possess his creative spirit. I carve sometimes, I even bend iron, and shape bronze.

BABA: (Chuckles again.) Ah! Omode o mogun oun pe le fo.

IYASE: What did you say baba?

BABA: A friendship with Ogun and Esu when not well watched ends up in excesses and blood. Who is Edai...Edai

IYASE: Edaiken.

BABA: He offended you and your pain burns to the bones. $(I Y, \text { p. } 21-22)^{7}$

This conversation is quoted in full to provide a complete picture of Iyase's belief in Ogun, his covenant with Ogun, and the influence of Esu on his belief. To reiterate, Orunmila or Ifa is the Yoruba god in charge of wisdom and foreknowledge. Usman and Falola (2019) opine that 'in Yorubaland, Orunmila or Ifa is the deputy of Olodumare, and he must be consulted before a major decision is taken, either involving an

\footnotetext{
${ }^{6}$ Some of these unrealistic promises are listed in Felix Ndubuisi's Nigeria, What Hope? (Quoted in Ike-Nwafor, 2016). They include "our vision is to banish poverty in Ekiti", "we are the messiahs", "better life for rural dwellers is assured if I am elected", "there will be free education, free medical care, uninterrupted power supply, good food and portable water on the table of every Nigerian",
}

\footnotetext{
${ }^{7}$ Translations: Ogun Onire. Yanka nnire olomi nile feje we, o laso nile fimokimo bora [directly translates as Ogun from Ire, he who has water but bathes with blood]. Esu Ebita ke [Esu is coming]. Laroye [another name for Esu]. Ebora tiije latopa, obelekun sunkun keru o ba elekun laroye [the spirit called Latopa, he who helps the crier to cry and the crier becomes scared]. Omode o mogun oun pe le fo [a child does not know herbs, he or she calls it vegetable]
} 
individual or community' (p. 275). The Yoruba people see Orunmila as their spiritual eyes. Owing to Orunmila's influence, every worship about other gods in Yorubaland features consulting him to know the gods' minds before making any decision. Suffice to mention that Iyase is a man of multiple beliefs after his mother brought Esu into the family. There can be a clash of rites to different gods in Africa. Some ritual materials can be used to worship Ogun and can be an abomination during the worship of Esu. For example, Ogun loves palm tree products like palm oil, palm kernel, palm fronds, and palm wine (Usman \& Falola 2019, p. 276), while Esu is abhorrent of the black extract from palm kernel seed. Baba's reference to the friendship between Esu and Ogun is reminiscent that either of the gods can be jealous if one gets more sacrifice than the other. As such, if one made a promise to Esu and did not fulfill it while he or she makes more sacrifices to Ogun, Esu will strike with confusion to get the adherent's attention. Usman and Falola depict Esu as a god primarily associated with calamites, mischief, and confusion and can create enmity between people. From a connective theory viewpoint, the chaos in Iyase's household occurs due to the clash of interest between Ogun and Esu worship. The effect will be commotion and unrest in Iyase's life. Iyase's ordeals became evident in the below extract between Omosefe and the Esu priestess that appeared in her dream:

OMOSEFE: No. But just now you reminded me of a covenant long promised and harvested. Why? Has my son not served you diligently too?

EDIGUN: He has. But lately he wobbles. He dances to the drums of another god. He forgets that we too are a jealous god, so now he ebbs...racing to a fall. As I stand, we are the only thread to life which he has. He basks under the cool shade of our wings, sadly oblivious of our protection. If he pushes us one more time Iyie, we shall fold them, and leave him the torrents of rain which threatens to fall. We remain faithful to our earlier promise. Should we flutter? I ask you woman?

OMOSEFE: I know. I will speak with him.

EDIGUN: Which possessed soul lies in waiting? Can we have her? The mark of Esu is on her forehead.

OMOSEFE: No. I shall give nothing. I owe nothing. I have nothing more to give. I have already given enough... Enough. (Pause.) But not tonight.

EDIGUN: Whenever, but soon. We saw it all. How your son slit the throat of his possessed wife. And how he gave her to Ogun whole... (IY, p. 55)

Using connective theory, it is vivid from the extract that Esu is jealous of how benevolent Iyase is to Ogun. Also, an offense or sin against any of the gods is a sin against the community. Iyase makes himself an Esu enemy by favoring one god over the other. 'We saw it all' (55) signifies that Esu is conversant with what transpired in Iyase's household, and as mentioned earlier, the god might have caused the confusion. The question is, is Esu responsible for Ivie's licentiousness? It is evident that Esu is fighting for recognition in Iyase's household, and for attention, confusion needs to arise in Iyase's family. It is later revealed in the text that Iyase was also a product of an illicit affair between Omosefe and the king (p. 53). Omosefe made a covenant with Esu before Iyase was born. She was married to Iyase's poor father. She decided to be overambitious and approached Esu to allow her to have affluence and recognition. In return, Esu requested her sight and her husband. Her husband died, and she became blind before the product of the illicit affair with the king, Iyase, was born. She swore to Esu to keep it a secret as long as Esu protects her and the child (p. 53). It is thus evident that Esu has control over Iyase, and for Iyase to make Ogun his god becomes an abomination.

Hence, the Yoruba people fear Ogun's action towards anyone who takes a bribe or manipulates breakthroughs. Ogun detests taking a bribe and shun corruption. The god acts swiftly to end any act of bribery and corruption. According to Idumwonyi and Ikhidero (2013), 'swearing with Ogun implement is taken very seriously because it is believed to possess a potential for instantaneous manifestation. Anyone who does not do the bidding of Ogun has surely set him/herself for a battle with the messenger of death' (p. 130). The 
effectiveness of the judgment inflicted by Ogun cannot be overemphasized because a Yoruba person will think twice before she or he takes a bribe or engages in any corrupt practice. Adekanbi's ordeals in Sacred Mutters become relevant here. To recall, he bribed Esu to manipulate the kingship choice in the Adeowo community ( $S M$, p. 42). The madwoman placed a curse on the young Prince that the gods will take him in 'broad daylight, with the villagers clapping and jeering' (p. 49).

From the viewpoint of connective theory, the madwoman's curse invoked the gods to deal with Adekanbi's misdemeanor. The question here is, since Adekanbi's part to make Esu accept his request is to mate a madwoman, what wrong or evil did he commit? Applying connective theory, the question could be answered in two ways. First, Adekanbi ignorantly refused to yield to Abese's warning to remove his clothes and beads. Adekanbi replied that 'he will go into this madness a prince that I am' (p. 48). Note the use of 'madness' in Adekanbi's response. He refers to the demand of the gods in exchange for the throne as madness. Second, the madwoman is a worshipper of Oya, the Yoruba river goddess. Abese, when describing the madwoman and where she stays, he mentions that 'she is there, my Prince, by the broken wall, eating the food I gave her... she sings for Oya throwing some bread into the pond' (p. 47). As mentioned earlier, the madwoman turns out to be Adekanbi's biological mother, who Olori Abike made to give birth to Adekanbi and claim her child after making her mad (p. 70). Like Omosefe's influence in Iyase's downfall, Olori Abike approached Esu to make Atinuke mad, took Adekanbi from her, and employ Sango to protect her from the aftermath of her actions. Her affiliation with Sango and Esu caused Adekanbi's downfall. Abike's fate is evident in Ifadare's response to Olori Abike after she denied making Atinuke mad and claiming her child. Ifadare says, 'let her go, Kabiesi. She must run to Sango for protection, not after ordering the death of Oya's worshipper, she too will meet her doom' (p. 71).

Ogun, Oya and Sango become central to the discussion for punishing offenders in both Sacred
Mutters and Iyase. For instance, in Sacred Mutters, confusion arose during Adekanbi's coronation when the madwoman returns with the king's royal bead (SM, p. 58). Balogun and other chiefs sent emissaries to consult Abore, the Ogun priest of the Adeowo community, to inquire about the commotion's cause. Abore reveals that Olori Abike bribed the kingmakers to use another bead during the installation and influenced the Adeowo community's kingship choice. Abore further indicates that the gods have rejected Adekanbi as the king and have requested him to commit suicide. Abore declares that the gods' request for Adekanbi's head and all his properties burnt before his burial. Also, his name is not to be mentioned in the community for seventeen years ( $S M$, p. 80). Adekanbi agrees to Ogun's demand for his head while his mother died from thunder strikes and fire, a symbol of punishment from Sango.

Similarly, in Iyase, the gods rejected Iyase due to his stubbornness and willingness to assert vengeance on Edaiken. He died by asking his blind mother to point the sword in his direction and ran into it before Edaiken, and the Benin warriors could arrive. After seventeen years, there was peace after Adekanbi's death, and a new king, Adewale, was installed.

\section{CONCLUSION}

From the analysis, the justice system of Africa has been polluted by the introduction and adoption of formal justice systems which have Western religions as their premise. The people no longer fear what is African and instead rely on their God of grace and mercy while committing a crime and hoping for a second chance. For instance, the Yoruba believe that every criminal act committed in the community makes the gods of the land angry. If the offender is not quickly detected and punished, the gods may punish the community as a whole with pestilence or death, as this paper's analysis emphasized. The gods work together to bring justice and peace whenever it is needed. The article, therefore, argues that a return to the African traditional judicial system will help reduce criminal activities in the community. Okunola \& Ojo (2012) aver that the Yoruba mostly avoided 
criminal acts before Western culture because of the fear of being destroyed by the gods. Such fear deterred most of them from engaging in illegal acts. Sometimes the gods strike the offender with madness, death, or any other punishment, even before such offender is known and brought before the traditional court. Hence, being born into an African community qualifies such a person to be tied to the gods' judgment. Being a Christian or Muslim does not mean swearing by the gods cannot incur their wrath; to maintain a corrupt-free community, people should use African gods' symbols to swear with, notwithstanding their religious view. The fear of retribution will not allow people to swear by the African god's symbols because they already know that judgment or punishment from African gods is instantaneous.

\section{REFERENCES}

Awolalu, J. O., \& Awolalu, J. O. (1979). Yoruba Beliefs and Sacrificial Rites. London: Longman.

Balogun, O. A. (2009). The Nature of Evil and Human Wickedness in Traditional African Thought: Further Reflections on the Philosophical Problem of Evil. Lumina, 20(2), 1-20.

Bamgboye, A. A. (2020). Assessing Access, Diagnosis, and Treatment in TB and HIV/AIDS Co-Infected Children in Pretoria. Masters Dissertation. Pretoria: Unisa.

Diora, L., \& Rosa, R. N. (2020). An analysis of Students' Difficulties in Listening Comprehension: A Descriptive Study at English Language and Literature Department FBS UNP. Journal of English Language Teaching, 9 (1), 85-98.

Dressler, J. (2005). The Wisdom and Morality of Present-Day Criminal Sentencing. Akron Law Review, 38(4), 853-866.

Famule, O.F. (2005) Art and spirituality: The Ijumu Northeastern-Yoruba Egungun. Doctoral Thesis. Arizona: University of Arizona.

Idowu, E. B (1966). Olodumare: god in Yoruba belief. London: Longmans.

Idumwonyi, I. M., \& Ikhidero, S. I. (2013). Resurgence of the Traditional Justice System in Postcolonial Benin (Nigeria) Society. African Journal of Legal Studies, 6(1), 123-135. https://doi.org/10.1163/17087384-12342017.

Ike-Nwafor, N.G (2016). Critical Discourse Analysis of Selected Political Campaign Speeches of Gubernatorial Candidates in South-Western Nigeria 2007-2014.
Doctoral Dissertation. UNIVERSITY OF NIGERIA, NSUKKA.

Jegede, O. B. (2006). Women, Power and Subversion in Orature: A Palace Performance in Yorubaland, Nigeria. Journal of gender studies, 15(3), 253-266. https://doi.org/10.1080/09589230600862000.

Jeyifo, B. (2003). Wole Soyinka: Politics, Poetics, and Postcolonialism (Vol. 9). Cambridge University Press.

Mbiti, J. S. (2015). Introduction to African religion. Illinois: Waveland Press.

Monye, M. (2004, April 24). Real Taboo and Prevention. Retrieved from: http://www.laits.utexas.edu/africa/2004/ database/monye.html.

National Council for Osteopathic Research. (2014 April 15). Quantitative Research Methods. Retrieved from http://www.ncor.org.uk/wpcontent/uploads/2014/03/Ouantitative re search methods.pdf.

Nwangama, E (2014). "Traditional Religious Concepts and Practices that Reflect the Justice and Human Dignity in Contemporary Africa." In Emezue MT, Kosch I and Kangel M (eds) Justice and Human Dignity in Africa. HPC BOOKS.

Ogunleye, A. R. (2015). Cultural Identity in the Throes of Modernity: An Appraisal of Yemoja among the Yoruba in Nigeria. Inkanyiso: Journal of Humanities and Social Sciences, 7(1), 60-68.

Okunola, R. A., \& Ojo, M. O. D. (2012). Re-assessing the Relevance and Efficacy of Yoruba Gods as Agents of Punishment: A Study of Sango and Ogun. Issues in Ethnology and Anthropology, 7(4), $1057-1076$

Oluwasuji, O (2019). Re-imagining Ogun in Selected Nigerian Plays: A Decolonial Reading. Pretoria: University of South Africa.

Ospina, S. (2004). Qualitative Research. In G. R. Goethals, G. J. Sorenson, \& J. MacGregor Burns (Eds.), Encyclopedia of leadership. London: Sage.

Oyeshile, O. A. (2000). Corruption and Underdevelopment in Nigeria. Recall: A Chronicle of Nigerian Events, 1(1), 53-59.

Oyetunji A. (2020, April 5). Operation Amotekun: Lagos, Osun, Ekiti to Recruit 1,320 Militiamen. Retrieved From: https://punchng.com/operation-amotekunlagos-osun-ekiti-to-recruit-1320-militiamen/.

Pemberton III, J. (1997). The Dreadful God and the Divine King. Africa's Ogun: Old World and New, 105-46. 
Punch NG Newspaper. (2016, April 26). Chibok Girls and Politics of Broken Promises. Available on http://punchng.com/chibok-girls-and-politicsof-broken-promises/

Ribeiro, I., \& Friaça, A. C. (1997). Cosmic Time and Individual in Yoruba Thought and Life. África, (18-19), 241-250.

Ugiagbe, E. O., Agbontaen-Eghafona, K., \& Omorogiuwa, T. B. E. (2007). An Evaluation Of The Principles of Primogeniture and Inheritance Laws Among the Benin People of Nigeria. Journal of Family History, 32(1), 90-101. https://doi.org/10.1177/0363199006294784.

Usman, A., \& Falola, T. (2019). The Yoruba from Prehistory to the Present. Cambridge: Cambridge University Press.
Utoh-Ezeajugh, T. C., \& Ogbonna, K. S. (2013). Cultural Imperatives for Peace and Security in African Drama: Ogonna Agu's. Creative Artist: A Journal of Theatre and Media Studies, 7(1), 12-31.

Warmelink, H, Harteveld C, and Mayer I (2009). Press Enter or Escape to Play-Deconstructing Escapism in Multiplayer Gaming. DiGRA Conference. Breaking New Ground: Innovation in Games, Play, Practice and Theory.

Young, W (1976). Escapism in Literature and Life. Neohelicon 4(3-4): 377-380.

Yerima, A. (2013). Sacred Mutters. Ibadan: Kraftgriots. Yerima, A. (2016). Iyase. Ibadan: Kraftgriots. 